International Research Journal of Management, IT \& Social Sciences
Available online at https://sloap.org/journals/index.php/irjmis/
Vol. 8 No. 1, January 2021, pages: 91-101
$\begin{aligned} & \text { ISSN: 2395-7492 } \\ & \text { https://doi.org/10.21744/irjmis.v8n1.1117 }\end{aligned}$

\title{
Good Corporate Governance Moderate the Effect of Financial Performance on Firm Value
}

\author{
Ni Pande Putu Wita Irwanti ${ }^{a}$
} Ni Made Dwi Ratnadi ${ }^{\text {b }}$

Article history:

Submitted: 27 November 2020

Revised: 18 December 2020

Accepted: 09 January 2021

\section{Keywords:}

companies;

financial performance;

firm value;

good corporate governance;

Indonesian stock exchange;

\begin{abstract}
This study aims to determine how the effect of financial performance on firm value with corporate governance as a moderating variable in the income smoothing companies listed on the Indonesia Stock Exchange 2015-2020. This study uses one independent variable (financial performance), one dependent variable (firm value), and one moderating variable (Good Corporate Governance). The sample used in this study were 40 income smoothing companies listed on the Indonesia Stock Exchange from 2015 to 2020 with a total of 240 pieces of data. The sampling technique used in this study was the purposive sampling technique. The results of hypothesis testing indicate that financial performance has a positive effect on firm value. Corporate governance can moderate the relationship between financial performance and firm value.
\end{abstract}

International research journal of management, IT and social sciences (C) 2021. This is an open access article under the CC BY-NC-ND license (https://creativecommons.org/licenses/by-nc-nd/4.0/).

Corresponding author:

Ni Pande Putu Wita Irwanti,

Faculty of Economics and Business, Udayana University, Denpasar, Indonesia.

Email address: wita.irwanti1988@gmail.com

a Faculty of Economics and Business, Udayana University, Denpasar, Indonesia

Faculty of Economics and Business, Udayana University, Denpasar, Indonesia 


\section{Introduction}

The presence of the capital market increases the choice of companies to obtain funding sources (especially long-term funds). This means that spending decisions are increasingly varied so that the company's capital structure can be optimized. The role of the capital market from the company side is the availability of funds from investors to the company, while from the investor's side it is hoped that they will get a return on the deposit of these funds. There are several parties with an interest in an entity, namely the owner of the company with an interest in the invested capital, the management with an interest in the reward (bonus) that will be obtained, the government has an interest in the taxes that will be imposed on the company and workers who have an interest in their welfare in the entity. There are often conflicts of interest between these interested parties, where each party wants to maximize its interests. The most obvious conflict of interest is between the company (principal) and the management. Principals want the company to be properly managed by management according to applicable rules to earn profits, while management wants the principals to get satisfaction with their work, which is shown by increasing profits from period to period to get rewards for their performance. Although to achieve this, the management did all kinds of ways.

The importance of earnings information is realized by management so that management tends to perform dysfunctional behavior (inappropriate behavior) which is influenced by the asymmetry of information in the concept of agency theory where each party, both the principal as shareholder and agent as company management, has different interests and wants to fight for it. their respective interests to encourage managers to carry out earnings management or manipulation of earnings (Assih \& Gudono, 2000). One of the management's actions on earnings that can be taken by management is income smoothing. The income smoothing action can be defined as a means used by management to reduce the variability of earnings reporting sequences relative to several target sequences which are seen due to the manipulation of accounting variables (Koch in Khafid, 2002). According to Eckel (1981), income smoothing can be produced from either natural smoothing or intentional smoothing or real smoothing or artificial smoothing. Natural smoothing implies that the profit process inherently produces an even flow of profit. Meanwhile, actual smoothing means income smoothing by choosing an accounting method and applying accounting procedures to transfer costs and/or income from one period to another to produce a certain profit flow.

The income smoothing concept assumes that investors are risk-averse, Fudenberg, and Tirole (in Khafid, 2002) and risk-averse managers are motivated to do income smoothing. Likewise, to creditors, managers prefer alternatives that produce equal profits Trueman and Titman (in Khafid, 2002). The results of Zuhroh (2004), study also show that there is a strong motivation that drives managers to income smoothing. Healy (1985), states that managers have a large enough incentive to smooth income to reduce fluctuations in company earnings so that it is expected that the company's performance will look better and investors will find it easier to predict future earnings. The company will choose accounting procedures that generate certain profits to meet the desired targets. Owners also try to encourage management to maximize their ability to achieve the targets set to make the entity look good and financially secure. Income smoothing is a logical and rational practice carried out by management, to the extent permitted by the principles of good accounting and management in Widana et al. (2013). Nevertheless, this income smoothing action resulted in misleading information regarding earnings which resulted in wrong decision-making by interested parties, especially for the company (Cahyati, 2010) in Widana et al. (2013).

Assessment of company performance is an activity that is very important because based on the results of this assessment, the measure of the company's success during a certain period can be known. The results of this assessment can be used as a guide for efforts to improve and improve the company's performance in the future (Sugiarso \& Winarni, 2005). According to Permana (2013), the measurement of financial performance is a fundamental aspect for investors to invest in because it reflects the real condition of the company. According to Ganto et al. (2008), stated that a good financial performance of a company is the main consideration for investors in making investment decisions. Improved financial performance is expected to increase the value of the company, where the higher the financial performance, the higher the value of the company (Davis \& Albright, 2004; Mahoney \& Roberts, 2007).

According to Puspitasari (2010), high company value will be followed by high prosperity for shareholders. The higher the stock price, the higher the company value which shows the company's prospects in the future. High company value will reflect if the company is well managed. Corporate governance mechanisms can oversee management and decision-makers, making it easier to maximize firm value (Handayani \& Yustikasari, 2017 in Restuningdiah, 2015). Also, corporate governance is expected to be able to overcome inconsistencies in the effect of financial performance on firm value.

Law No. 40 of 2007 concerning Limited Liability Companies also regulates the implementation of corporate governance that is run by the company. Good corporate governance creates mechanisms and means of control to enable 
the creation of a balanced system of profit and wealth sharing for stakeholders and creates efficiency for the company (Nuswandari, 2009). The corporate governance structure will create a distribution of rights and obligations between the various parties involved in the company (Sugiyanto, 2011).

The implementation of good corporate governance will make the company gain the trust of investors. Research conducted by Sukasih (2011), shows that the impact of implementing good corporate governance is to increase the company's financial performance as a result of the low risk that must be borne by investors due to the guaranteed safety of funds invested in the company. Research conducted by Mahendra et al. (2012), found that financial performance has a positive effect on firm value, the higher the company's financial performance, the company can generate high returns for shareholders and increase firm value. Subiyantoro \& Andreani (2003) found that the company's financial performance had a positive effect on the company's stock price, high stock prices could reflect high firm value. Amri \& Untara (2012), also prove that the company's financial performance has a positive effect on firm value.

Salno \& Baridwan (2000), found that there is no difference in returns between smoothing firms and non-income smoothing firms. Assih (1998), found evidence that market reactions as measured by cumulative abnormal returns between income smoothing firms differ significantly from non-income smoothing firms. Samlawi (1999), concluded that in the analysis of the total sample, it was found that there was a significant difference in average returns between average firms and non-average firms (average return of average firms was smaller than non-average firms). Meanwhile, the latest research conducted by Khafid (2002), found empirical evidence that there is a difference in market reactions as measured by cumulative abnormal returns between different income smoothing companies and non-income smoothing companies.

Samlawi (1999), identifies factors that can encourage income smoothing practices including firm value, operating leverage, company size, the existence of bonus planning, and the industrial sector. High company value will reflect if the company is well managed. Ulupui (2007), states that firm value is determined by the earnings power of the company's assets. A positive result shows that the higher the earnings power, the more efficient the asset turnover is and or the higher the profit margin the company gets. Research conducted by Ulupui (2007) found that financial performance has a significant positive effect on stock returns for the next period. Therefore, financial performance is one of the factors that influence firm value. Ratih \& Setyarini (2014), also found that financial performance has a positive effect on firm value. Different results obtained by Anggitasari \& Siti (2012), found that financial performance as proxied by ROA does not have a significant effect on firm value. Suranta \& Pratana (2004), in their research, found that financial performance hurts firm value. Carningsih (2012), research found that financial performance does not affect firm value. Similarly, research conducted by Puspitasari (2010), found that financial performance hurts firm value.

The difference in the results of the research is interesting for re-research (replication) on this topic. The author includes corporate governance as a moderating variable that is thought to have contributed to strengthening or weakening this influence. Corporate governance is a concept based on agency theory and is expected to serve as a tool to provide confidence to investors that they will receive a return on the funds they have invested (Restuningdiah, 2015). Corporate governance provides a structure that facilitates the determination of the goals of a company, and as a means of determining performance monitoring techniques (Rodriguez-Fernandez, 2016). This study uses financial performance with the proxy of Return on Asset as an independent variable because it can measure the efficiency of the company in carrying out operational activities. Return on Asset is also a fundamental ratio that can measure the level of company profitability. Firm value is proxied by Tobin's $\mathrm{Q}$ because the Tobin's $\mathrm{Q}$ ratio can provide information about the state of the company whether it is growing, stagnant, or decreasing so that investors can make the right decisions (Mak \& Kusnadi, 2005; Villalonga \& Amit, 2006; Putri \& Rahyuda, 2020).

Corporate governance is chosen as a moderating variable because corporate governance is a form of monitoring from the principal to the agent which will certainly reduce agency costs that arise as a result of a conflict of interest between the principal and agent (Jensen \& Meckling, 1976). Florackis \& Ozkan's (2009) research examines the effect of GCG implementation on agency cost and finds that for companies that perform good governance, it is indicated by ownership, board composition, and the formation of an audit committee and external auditors can significantly reduce the number of agency costs. for the company concerned. This research is supported by Ibrahim \& Samad (2009), and Gul et al. (2017), which states that corporate governance can significantly reduce agency costs. With a well-structured and well-structured company management, it can increase transparency and accountability and can control manager behavior so that it is not only beneficial for themselves but benefits stakeholders so that it is expected to increase company performance and value. Anggitasari \& Siti (2012), the research includes corporate governance as a moderating variable, and the results of their research show that institutional ownership can moderate the relationship between performance and firm value.

Irwanti, N. P. P. W., \& Ratnadi, N. M. D. (2021). Good corporate governance moderate the effect of financial performance on firm value. International Research Journal of Management, IT and Social Sciences, 8(1), 91-101. https://doi.org/10.21744/irjmis.v8n1.1117 
Literature review and hypothesis development

Financial performance is one of the factors that become the reference for investors in buying shares. For companies, improving financial performance is a must so that company shares remain attractive to investors. The level of financial performance depends on the management of the company's assets which reflects the company's operational efficiency. The higher the financial performance, the more efficient the company's operations are. According to Hamonangan \& Macfoedz (2006), the firm value will decrease if the quality of company earnings is low. The low quality of company earnings can lead to mistakes in making decisions for investors or creditors (Hamonangan and Mas'ud). Also, research conducted by Wijaya \& Linawati (2015), states that Return On Asset (ROA) has a significant positive effect on corporate value, while research conducted by Hermawan and Afiyah Nurul Maf'ulah (2014), states financial performance (ROA). ) has no significant effect on firm value. Profitability is the company's ability to make a profit. The profit the company gets comes from sales and investments made by the company. Profitability is also a description of management performance in managing the company. The higher the value of the ROA ratio, the higher the company's ability to generate profits which results in high profitability. The high profitability value of the company will give a positive signal to investors or creditors that the company is in a favorable condition, this will attract investors to own the company's shares. The high demand for shares will make investors appreciate the value of shares greater than the recorded value in the company value so that the company value will be high.

H1: Financial performance has a positive effect on firm value

According to Kanagaretnam et al. (2007), one of the benefits of corporate governance is to reduce agency costs. Good corporate governance (GCG) will reduce conflicts between principals and agents with supervision, thereby reducing the possibility for managers to take opportunistic actions. The implementation of good corporate governance can provide effective protection for investors in recovering their investment fairly (Tjager, 2003). Corporate governance is a way to provide confidence to investors that they will get a return on the investment that has been made in the company (Shleifer \& Vishny, 1986). According to Luhukay (2002) in Nuswandari (2009), some parties consider openness and information about corporate governance to be more important than corporate financial information. Research by Retno \& Priantinah (2012), proves that corporate governance has a positive effect on firm value, which is proxied by the Tobin's Q ratio. According to Sukasih (2011), the implementation of corporate governance in companies can improve the company's financial performance because investors feel safe with invested funds. so that it will reduce the company's cost of capital. According to research by Love \& Klapper (2002); Black et al., (2003); and Da Silveira \& Barros (2007), it shows that the higher the level of transparency on the implementation of good corporate governance, the higher the firm value as indicated by the high stock prices. company. According to Retno \& Priantinah (2012), corporate governance mechanisms can create a balance between various interests that can provide benefits for the company as a whole. Anggitasari \& Siti (2012), shows that corporate governance proxied through institutional ownership can moderate the relationship between financial performance and firm value. Good corporate governance (GCG) will reduce conflicts between principals and agents with supervision, thereby reducing the possibility for managers to take opportunistic actions.

H2: corporate governance can moderate the relationship between financial performance and firm value.

\section{Materials and Methods}

This research was conducted at income smoothing companies listed on the Indonesia Stock Exchange (BEI) in 20152020. Income smoothing companies tend to have stable financial performance compared to non-income smoothing companies. Financial performance that is deliberately stabilized will result in asymmetry of information received by investors. The implementation of good corporate governance is expected to be able to reduce the practice of income smoothing so that go public companies can provide accurate information about the company's financial performance. Sources of data in this study are secondary data, namely the annual reports of companies that have smoothed profits for the years 2015-2020. The population in this study were all companies listed on the Indonesia Stock Exchange in 2015-2020. The purposive sampling technique was used as a method of sampling. Data analysis techniques using interaction tests or often referred to as moderated regression analysis (MRA) is a special application of linear multiple regression where the regression equation contains elements of interaction (Ghozali, 2012). The statistical equation formula used is as follows: 
Information:

$$
\mathrm{NP}=\alpha+\beta 1 \mathrm{KK}+\beta 2 \mathrm{CG}+\beta 3 \mathrm{KK} * \mathrm{CG}+\mathrm{e}
$$

$\mathrm{NP}=$ Firm value

$\mathrm{KK}=$ financial performance

$\mathrm{CG}=$ Corporate governance

$\alpha=$ constant

$\beta 1-\beta 3=$ Regression coefficient

$\mathrm{e}=$ standard error

If in equation 6 the regression coefficient value $\beta 3$ has a significance level smaller than $\alpha=0.05$, it can be said that corporate governance is a moderating variable that affects the positive relationship between financial performance and firm value.

\section{Results and Discussions}

\section{Interaction Test}

The following results of the interaction test in this study are presented in Table 1.

Table 1

Results of a model I regression analysis

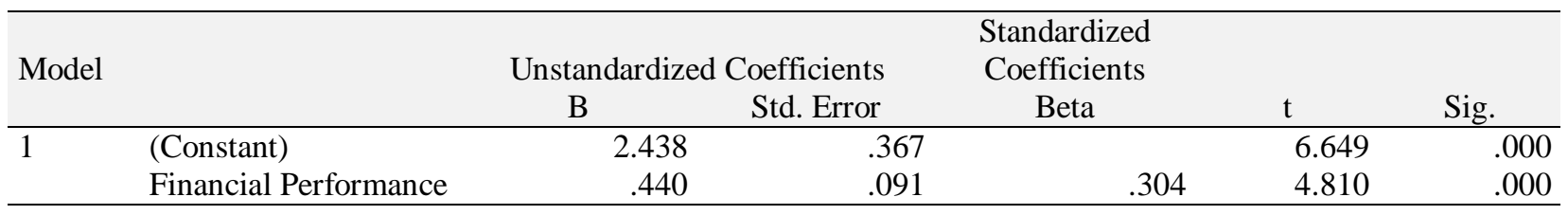

Table 2

Results of model II regression analysis

\begin{tabular}{|c|c|c|c|c|c|c|}
\hline \multirow[t]{2}{*}{ Model } & & Unstandardized & Coefficients & $\begin{array}{l}\text { Standardized } \\
\text { Coefficients }\end{array}$ & \multirow[b]{2}{*}{$\mathrm{t}$} & \multirow[b]{2}{*}{ Sig. } \\
\hline & & $\mathrm{B}$ & Std. Error & Beta & & \\
\hline \multirow[t]{4}{*}{1} & (Constant) & 1.876 & .429 & & 4.370 & .000 \\
\hline & Financial Performance & .433 & .102 & .299 & 4.237 & .000 \\
\hline & Corporate Governance & .154 & .076 & .131 & 2.025 & .044 \\
\hline & $\mathrm{X} * \mathrm{Z}$ & .101 & .040 & .104 & 2.525 & .032 \\
\hline
\end{tabular}

Secondary Data, 2020

The t statistical test shows the partial effect of the variable KK (ROA), CG, and KK * CG on NP (Tobin's Q). Based on the results of the $t$ statistical test above, the following regression equation can be made:

$\mathrm{Y}=2.438+0.440 \mathrm{X}($ Model I)

$\mathrm{Y}=1.876+0.433 \mathrm{KK}+0.154 \mathrm{CG}+0.101 \mathrm{KK} * \mathrm{CG}+\mathrm{e}($ Model II $)$

\section{The coefficient of determination}

In the table below it can be seen that the determination test of the overall regression results of the correlation between the dependent variable and the independent variable:

Irwanti, N. P. P. W., \& Ratnadi, N. M. D. (2021). Good corporate governance moderate the effect of financial performance on firm value. International Research Journal of Management, IT and Social Sciences, 8(1), 91-101. https://doi.org/10.21744/irjmis.v8n1.1117 
Table 3

Determination Test

\begin{tabular}{lrrrr}
\hline Model & R & R Square & Adjusted R Square & Std. Error of the Estimate \\
\hline 1 & $.341^{\mathrm{a}}$ & .116 & .104 & 3.15384 \\
\hline Secondary Data, 2020 & & & &
\end{tabular}

The R-value of 0.341 means that the level of correlation between the variation of the independent variable and the dependent variable is $34.1 \%$, meaning that the firm value (NP) has a weak relationship with KK, CG, and the KK * $\mathrm{CG}$ interaction variable because of the correlation coefficient $<0.5$. The coefficient of determination $\left(\mathrm{R}^{2}\right)$ of 0.116 means that the model's ability to explain the variations in the dependent variable is $11.6 \%$. The Adjusted $\mathrm{R}^{2}$ value of 0.104 indicates that $10.4 \%$ of firm value (Tobin's Q) can be explained by the variable KK (ROA), CG, and the KK * CG interaction variable while the remaining $89.6 \%$ is explained by other variables that are not included. into the model. The Standard Error of the Estimate value is 0.3153 , indicating that the smaller the Standard Error of the Estimate value, the more precise the regression model will be in predicting the dependent variable.

\section{Simultaneous significance test (F statistical test)}

It can be seen in Table 4 that the calculated $F$ value in this research model is 9,892 with a significant value of 0,000 . A significant value of less than 0.05 indicates that the regression model can be used to predict firm value.

Table 4

Statistical test F

\begin{tabular}{llrrrrr}
\hline Model & & Sum of Squares & df & Mean Square & F & Sig. \\
\hline 1 & Regression & 295.167 & 3 & 98.389 & 9.892 & $.000^{\mathrm{b}}$ \\
& Residual & 2247.956 & 226 & 9.947 & & \\
& Total & 2543.123 & 229 & & & \\
\hline
\end{tabular}

Secondary Data, 2020

\section{The T-test (Significance Test of Individual Parameters)}

The $\mathrm{t}$ statistical test was carried out to show how far the influence of one independent variable individually in explaining the variation of the dependent variable (Kusumadilaga, 2010). The significance value (Sig) in the table is below $<0.05$, indicating that there is an influence between the independent variable and the dependent variable.

Table 5

Statistical test $\mathrm{t}$

\begin{tabular}{|c|c|c|c|c|c|c|}
\hline \multirow[t]{2}{*}{ Model } & & \multicolumn{2}{|c|}{ Unstandardized Coefficients } & \multicolumn{3}{|l|}{$\begin{array}{l}\text { Standardized } \\
\text { Coefficients }\end{array}$} \\
\hline & & B & Std. Error & Beta & $\mathrm{t}$ & Sig. \\
\hline 1 & (Constant) & 2.438 & .367 & & 6.649 & .000 \\
\hline & Financial performance & .440 & .091 & .304 & 4.810 & .000 \\
\hline
\end{tabular}

Secondary Data, 2020

\section{Effect of Financial Performance on Firm Value}

In Table 1 above, the significance level is obtained at 0.000 and the significance value is smaller than Los (level of significance) $0.05(\alpha=5 \%)$, then H1 which says Financial performance has a positive effect on accepted firm value $(0.000<0.05)$. Based on the results of regression model 1 in Table 5 , it is found that the company's financial performance as measured by return on assets (ROA) has a positive effect on firm value as measured by Tobin's Q. Return on assets is used to measure the amount of net income that can be obtained from company operations by using all his wealth. A positive ROA indicates that the total assets used for the company's operations can provide profits for 
the company. Conversely, if the ROA is negative, it shows that the total assets used are not profitable. Therefore, the more positive the value of ROA will show good financial performance which will be followed by an increase in the share price of the company.

Based on the hypothesis testing that has been done, it is found that financial performance, which is proxied by ROA, has a positive effect on firm value. This means that a positive ROA indicates that the assets used for the company's operations can provide profits for the company. The higher the value of the ROA ratio, the higher the company's ability to generate profits which results in high profitability. The high profitability value of the company will give a positive signal to investors or creditors that the company is in a favorable condition, this will attract investors to own the company's shares. The high demand for shares will make investors appreciate the value of shares greater than the recorded value in the company value so that the company value will be high.

The results of this study confirm some of the results of previous studies such as research conducted by Ab Razak et al. (2008) and Yuniasih \& Wirakusuma (2007), which found that financial performance has a positive effect on firm value. Modigliani \& Miller (1958), stated that firm value is determined by the company's earnings power assets. The positive effect of earnings power assets on firm value shows that the higher the earnings power, the more efficient the asset turnover will be, and the higher the profit margin the company gets so that it has an impact on increasing firm value. Puspitasari (2010) also found that financial performance has a positive effect on firm value.

\section{Effect of corporate governance on the relationship between financial performance and firm value}

The interaction variable between financial performance and corporate governance $(\mathrm{X} * \mathrm{Z})$ as shown in Table 2 has a positive coefficient value of 0.101 with a significance level of 0.032 . The positive influence of the interaction variable indicates that corporate governance can strengthen the relationship between firm performance and firm value.

\section{Hypothesis 2 is acceptable}

The results of statistical data analysis prove that corporate governance has a positive effect on the relationship between financial performance and firm value. This means that corporate governance can strengthen the relationship between company performance and firm value. Well-structured and well-structured company management can increase transparency and accountability and can control the behavior of managers so that they not only benefit themselves but benefit stakeholders. The implementation of good corporate governance can improve the company's financial performance as a result of the low risk that must be borne by investors due to the assurance of the safety of funds invested in the company.

The results of this study confirm some of the results of previous studies such as research conducted by Retno \& Priantinah (2012), proving that corporate governance has a positive effect on firm value as proxied by Tobin's Q ratio. According to Sukasih (2011), the implementation of corporate governance in companies can improve the company's financial performance because investors feel secure on invested funds so that it will reduce the company's cost of capital. According to research by Love \& Klapper (2002); Black et al. (2003); and Da Silveira \& Barros (2007), it shows that the higher the level of transparency on the implementation of good corporate governance, the higher the firm value as indicated by the high stock prices. company. According to Retno \& Priantinah (2012), corporate governance mechanisms can create a balance between various interests that can provide benefits for the company as a whole. Anggitasari \& Siti (2012), shows that corporate governance proxied through institutional ownership can moderate the relationship between financial performance and firm value.

\section{Research Implications}

This research has theoretical implications, especially in the development of accounting science related to financial performance, corporate governance, and firm value. Theoretically, this research also contributes to agency theory (agency theory), where information asymmetry in this study occurs when the company's internal information is relatively large and the information is relatively faster than external parties. So, what can be done is to use the information to manipulate financial reporting to maximize its prosperity. One of the management's actions on earnings that can be taken by management is income smoothing. The findings of this study indicate that financial performance has a positive effect on firm value and the contribution of corporate governance to strengthen the relationship between financial performance and firm value.

Irwanti, N. P. P. W., \& Ratnadi, N. M. D. (2021). Good corporate governance moderate the effect of financial performance on firm value. International Research Journal of Management, IT and Social Sciences, 8(1), 91-101. https://doi.org/10.21744/irjmis.v8n1.1117 
The results showed that there was a positive influence on financial performance and had a positive effect on firm value and the contribution of corporate governance to strengthen the relationship between financial performance and firm value. These findings are relevant to investors' perceptions that companies that have stable or high returns each year are considered capable of providing high returns for investors, such as large dividends each year. To increase profits, the profit smoothing company must be able to carry out management in terms of marketing to increase sales, HR management to improve service to customers, and financial management to manage sources of funds, both capital, and profits earned by the company.

\section{Conclusion}

The company financial performance as measured by return on assets (ROA) has a positive effect on firm value as measured by Tobin's Q. Return on assets is used to measure the amount of net income that can be obtained from company operations by using all of its assets. Corporate governance can strengthen the relationship between company performance and firm value. For future researchers who take the same research topic, it is better to use a larger sample size. A large sample will make research results better. And it is hoped that the next researchers will be able to expand the corporate sector, to be able to contribute to all companies.

\section{Research Limitations}

There are several limitations in the process of implementing and completing this research and it can be used as a reference for further, better research. Some of these limitations include:

1) The object of research is only limited to income-leveling companies, therefore for further research, it is better to use a larger sample.

2) The span of the research year is less long, therefore for further research, it is better to use a longer research year.

Conflict of interest statement

The authors declared that they have no competing interests.

Statement of authorship

The authors have a responsibility for the conception and design of the study. The authors have approved the final article.

Acknowledgments

We are grateful to two anonymous reviewers for their valuable comments on the earlier version of this paper. 


\section{References}

Ab Razak, N. H., Ahmad, R., \& Aliahmed, H. J. (2008). Government ownership and performance: An analysis of listed companies in Malaysia. Corporate Ownership and Control, 6(2), 434-442.

Amri, C., \& Untara, D. S. (2012). Analisis Pengaruh Kinerja Keuangan, Good Corporate Governance dan Corporate Social Responsibility Terhadap Nilai Perusahaan.

Anggitasari, N., \& SITI, M. (2012). Pengaruh kinerja keuangan terhadap nilai perusahaan dengan pengungkapan corporate social responsibility dan struktur good corporate governance sebagai variabel pemoderasi (Doctoral dissertation, Fakultas Ekonomika dan Bisnis).

Assih, P. (1998). Hubungan tindakan perataan laba dan reaksi pasar atas pengumuman informasi laba perusahaan yang terdapat di Bursa Efek Jakarta (Doctoral dissertation, Tesis S2 UGM).

Assih, P., \& Gudono, G. (2000). Hubungan Tindakan Perataan Laba dengan Reaksi Pasar atas Pengumuman Informasi Laba Perusahaan yang Terdaftar di Bursa Effek Jakarta. The Indonesian Journal of Accounting Research, 3(1).

Black, B. S., Jang, H., \& Kim, W. (2003). Does corporate governance affect firm value?: evidence from Korea. University of Chicago Law School, Law and Economics Workshop.

Cahyati, A. D. (2010). Implikasi Tindakan Perataan Laba Terhadap Pengambilan Keputusan Bagi Investor. JRAK: Jurnal Riset Akuntansi \& Komputerisasi Akuntansi, 1(02), 4449.

Carningsih, C. (2012). Pengaruh Good Corporate Governance Terhadap Hubungan Antara Kinerja Keuangan Dengan Nilai Perusahaan (Studi Kasus Pada Perusahaan Property Dan Real Estate Yang Terdaftar Di Bursa Efek Indonesia).

Da Silveira, A. D. M., \& Barros, L. A. B. D. C. (2007). Corporate governance quality and firm value in Brazil. Universidade de Sao Paulo, Working Paper.

Davis, S., \& Albright, T. (2004). An investigation of the effect of balanced scorecard implementation on financial performance. Management accounting research, 15(2), 135-153. https://doi.org/10.1016/j.mar.2003.11.001

Eckel, N. (1981). The income smoothing hypothesis revisited. Abacus, 17(1), 28-40.

Florackis, C., \& Ozkan, A. (2009). Managerial incentives and corporate leverage: evidence from the United Kingdom. Accounting \& Finance, 49(3), 531-553.

Ganto, J., Khadafi, M., Albra, W., \& Syamni, G. (2008). Pengaruh kinerja keuangan perusahaan manufaktur terhadap return saham di bursa efek indonesia. Media Riset Akuntansi, Auditing \& Informasi, 8(1), 85-96.

Gozhali, I. (2012). Aplikasi Analisis Multivariate dengan Program IBM SPSS 20.Edisi 6. Semarang: Badan Penerbit Universitas Diponegoro.

Gul, S., Muhammad, F., \& Rashid, A. (2017). Corporate governance and corporate social responsibility: The case of small, medium, and large firms. Pakistan Journal of Commerce and Social Sciences (PJCSS), 11(1), 1-34.

Hamonangan, S., \& Macfoedz, M. U. (2006). Mekanisme Corporate Governance. Kualitas Laba dan Nilai.

Handayani, Y. D., \& Yustikasari, Y. (2017). Corporate governance and audit report lags at manufacturing companies in the industrial sector of consumption goods. Corporate Governance, 9(29).

Healy, P. M. (1985). The effect of bonus schemes on accounting decisions. Journal of accounting and economics, 7(13), 85-107.

Hermawan, S., \& Afiyah Nurul Maf ulah.(2014). Pengaruh Kinerja Keuangan Terhadap Nilai Perusahaan Dengan pengungkapan Corporate Social Responsibity Sebagai Variabel Pemoderasi. Jurnal Dinamika Akuntansi, 6(2), 103-118.

Ibrahim, A. M., \& Abd El-Samad, G. A. (2009). Effect of different irrigation regimes and partial substitution of Nmineral by organic manures on water use, growth and productivity of pomegranate trees. European Journal of Scientific Research, 38(2), 199-218.

Jensen, M. C., \& Meckling, W. H. (1976). Theory of the firm: Managerial behavior, agency costs and ownership structure. Journal of financial economics, 3(4), 305-360. https://doi.org/10.1016/0304-405X(76)90026-X

Kanagaretnam, K., Lobo, G. J., \& Whalen, D. J. (2007). Does good corporate governance reduce information asymmetry around quarterly earnings announcements?. Journal of Accounting and Public Policy, 26(4), 497-522. https://doi.org/10.1016/j.jaccpubpol.2007.05.003

Khafid, M. (2002). Analisis Income Smoothing: Pengaruhnya terhadap Reaksi Pasar dan Risiko Investasi pada Perusahaan Publik di Indonesia (Doctoral dissertation, Program Pascasarjana Universitas Diponegoro).

Kusumadilaga, R. (2010). Pengaruh corporate social responsibility terhadap nilai perusahaan dengan profitabilitas sebagai variabel moderating (Studi empiris pada perusahaan manufaktur yang terdaftar di Bursa Efek Indonesia) (Doctoral dissertation, Perpustakaan FE UNDIP).

Irwanti, N. P. P. W., \& Ratnadi, N. M. D. (2021). Good corporate governance moderate the effect of financial performance on firm value. International Research Journal of Management, IT and Social Sciences, 8(1), 91-101. https://doi.org/10.21744/irjmis.v8n1.1117 
Love, I., \& Klapper, L. F. (2002). Corporate governance, investor protection, and performance in emerging markets. The World Bank.

Luhukay, J. (2002). Tata Pamong dan Nilai Perusahaan. Warta Ekonomi, 21.

Mahendra, Dj, A.., Artini, L. G. S., \& Suarjaya, A. G. (2012). Pengaruh kinerja keuangan terhadap nilai perusahaan pada perusahaan manufaktur di Bursa Efek Indonesia. Jurnal Manajemen, Strategi Bisnis, dan Kewirausahaan, 6(2), 130-138.

Mahoney, L., \& Roberts, R. W. (2007, September). Corporate social performance, financial performance and institutional ownership in Canadian firms. In Accounting forum (Vol. 31, No. 3, pp. 233-253). No longer published by Elsevier. https://doi.org/10.1016/j.accfor.2007.05.001

Mak, Y. T., \& Kusnadi, Y. (2005). Size really matters: Further evidence on the negative relationship between board size and firm value. Pacific-Basin finance journal, 13(3), 301-318. https://doi.org/10.1016/j.pacfin.2004.09.002

Modigliani, F., \& Miller, M. H. (1958). The cost of capital, corporation finance and the theory of investment. The American economic review, 48(3), 261-297.

Nuswandari, C. (2009). Pengaruh corporate governance perception index terhadap kinerja perusahaan pada perusahaan yang terdaftar di bursa efek Jakarta. Jurnal Bisnis dan Ekonomi, 16(2).

Permana, D. M. R. A. (2013). Kemampuan Pengungkapan Tanggung Jawab Sosial Perusahaan Dalam Memoderasi Hubungan Antara Kinerja Keuangan Dengan Nilai Perusahaan Pada Perusahaan Yang Terdaftar Di Indeks Kompas 100. Kumpulan Tesis Program PascasarjanaUniversitasUdayana, 1-95.

Puspitasari, R. E. (2012). Pengaruh Kinerja Keuangan Terhadap Nilai Perusahaan Dengan Pengungkapan Corporate Social Responsibility Dan Good Corporate Governance Sebagai Variabel Pemoderasi (Sensus Pada Perusahaan Manufaktur Di Bursa Efek Indonesia). Jurnal. Program Studi Akuntansi Fakultas Ekonomi Universitas Siliwangi Tasikmalaya.

Putri, I. G. A. P. T., \& Rahyuda, H. (2020). Effect of capital structure and sales growth on firm value with profitability as mediation. International research journal of management, IT and social sciences, 7(1), 145-155.

Ratih, S., \& Setyarini, Y. (2014). Pengaruh Good Corporate Governance (Gcg) Dan Corporate Social Responsibility (Csr) Terhadap Nilai Perusahaan Dengan Kinerja Keuangan Sebagai Variable Intervening Pada Perusahaan Pertambangan Yang Go Public Di Bei. AKRUAL: Jurnal Akuntansi, 5(2), 115-132.

Restuningdiah, N. (2015). Perataan Laba Terhadap Reaksi Pasar Dengan Mekanisme GCG Dan CSR Disclosure Penelitian Pada Perusahaan Yang Listed Di Bursa Efek Indonesia. International Research Journal of Business Studies, 3(3).

Retno, R. D., \& Priantinah, D. (2012). Pengaruh good corporate governance dan pengungkapan corporate social responsibility terhadap nilai perusahaan (studi empiris pada perusahaan yang terdaftar di Bursa Efek Indonesia periode 2007-2010). Nominal: Barometer Riset Akuntansi dan Manajemen, 1(2), 99-103.

Rodriguez-Fernandez, M. (2016). Social responsibility and financial performance: The role of good corporate governance. BRQ Business Research Quarterly, 19(2), 137-151. https://doi.org/10.1016/j.brq.2015.08.001

Salno, H. M., \& Baridwan, Z. (2000). Analisis perataan penghasilan (income smoothing): faktor-faktor yang mempengaruhi dan kaitannya dengan kinerja saham perusahaan publik di Indonesia. The Indonesian Journal of Accounting Research, 3(1).

Samlawi, A. (1999). Analisis perilaku perataan laba didasarkan pada kinerja perusahaan di pasar (Doctoral dissertation, [Yogyakarta]: Universitas Gadjah Mada).

Shleifer, A., \& Vishny, R. W. (1986). Large shareholders and corporate control. Journal of political economy, 94(3, Part 1), 461-488.

Subiyantoro, E., \& Andreani, F. (2003). Analisis faktor-faktor yang mempengaruhi harga saham (Kasus perusahaan jasa perhotelan yang terdaftar di pasar modal Indonesia). Jurnal Manajemen dan kewirausahaan, 5(2), 171-180.

Sugiarso, G., \& Winarni, F. (2005). Manajemen Keuangan. Media Pressindo: Yogyakarta.

Sugiyanto, E. K. (2011). Peningkatan Return Saham dan Kinerja Keuangan melalui Corporate Social Responsibility dan Good Corporate Governance. Jurnal Ilmiah Aset, 13(1), 47-56.

Sukasih, S. AS. 2011. Dampak Good Corporate Governance (GCG) terhadap Kinerja Perusahaan (Studi Kasus di Bursa Efek Indonesia). Jurnal Bisnis dan Kewirausahaan, 7(3), 197-205.

Suranta, E., \& Merdistuti, P. P. (2004). Income Smoothing, Tobin's Q, Agency Problems dan Kinerja Perusahaan. Simposium Nasional Akuntansi VII, 340-357.

Tjager, I. N. (2003). Corporate governance: Tantangan dan kesempatan bagi komunitas bisnis Indonesia. Prenhallindo. 
Ulupui, I. G. (2007). Analisis pengaruh rasio likuiditas, leverage, aktivitas, dan profitabilitas terhadap return saham (studi pada perusahaan makanan dan minuman dengan kategori industri barang konsumsi di BEJ). Jurnal Ilmiah Akuntansi dan Bisnis, 2(1).

Villalonga, B., \& Amit, R. (2006). How do family ownership, control and management affect firm value?. Journal of financial Economics, 80(2), 385-417. https://doi.org/10.1016/j.jfineco.2004.12.005

Widana, I. N. A. N., Ari, N., \& Yasa, G. W. (2013). Perataan laba serta faktor-faktor yang mempengaruhinya di bursa efek Indonesia. E-Jurnal Akuntansi Universitas Udayana, 3(2), 297-317.

Wijaya, A., \& Linawati, N. (2015). Pengaruh kinerja keuangan terhadap nilai perusahaan. Finesta, 3(1), 46-51.

Yuniasih, N. W., \& Wirakusuma, M. G. (2007). Pengaruh kinerja keuangan terhadap nilai perusahaan dengan pengungkapan corporate social responsibility dan good corporate governance sebagai variabel pemoderasi. Jurnal Ilmiah Akuntansi dan Bisnis, 4(1).

Zuhroh, S. (2004). Pengaruh Faktor Fundamental Perusahaan Terhadap Pendapatan Saham Pasca Publikasi Laporan Keungan Pada Kelompok Industri Makanan Dan Minuman Di BEJ (Doctoral dissertation, Universitas Airlangga).

Irwanti, N. P. P. W., \& Ratnadi, N. M. D. (2021). Good corporate governance moderate the effect of financial performance on firm value. International Research Journal of Management, IT and Social Sciences, 8(1), 91-101. https://doi.org/10.21744/irjmis.v8n1.1117 